\section{UNIVERSITY AND EDUCATIONAL} INTELLIGENCE

Edinburgh. - Five Fellowships in connection with this University (the gift of an anonymous donor) of the value of Iool. each, for one year, but renewable for one or two further years at the pleasure of the Senatus Academicus, will be open to applicants in October next. There will be no examinations for election to these Fellowships, but Fellows will be elected by the Senatus Academicus after consideration of the qualifications and circumstances of the applicants. The Fellowships are open to any graduate of a Scottish University, not being more than thirty years of age at the date of application, and provided that he be not an assistant to any Professor, or an examiner in any department. They are intended for persons having attained some proficiency in, and who are desirous to prosecute, unprofessional study and research in one of the following subjects :-Mathematics (pure and applied), or experimental physics, chemistry, biology, mental philosophy, history, or the history of literature. Persons desiring to hold one of these Fellowships should address an application to the secretary of the Senatus, with statement as to previous course of study, and general purposes with respect to future work. Each Fellow will be expected to reside in Edinburgh during the winter and summer sessions of the University (1882-83) to prosecule his particular branch of study under the advice of the Professor to whose department the subject belongs ; and within a year after his election to give evidence of his progress by the preparation of a thesis, the completion of a research, the delivery of a lecture, or in some other way approved by the Senatus Academicus. No other fellowship, scholarship, or bursary, in this or any other University, will be tenable together with one of the elective Fellowships.

THE budget commission of the French Chamber of Deputies have printed their estimates for public instruction for 1883 . They claim $5 \frac{1}{2}$ millions sterling, irrespective of the sums granted by departments for the same purpose. About half of this sum is claimed for elementary instruction, exhibiting, an addition of more than $800,000 \%$. on the credit given for I882. This is in prevision of the working of the law of compulsory education. The more notable items are the following:-Government grant to the grammar schools for young ladies, 12,000l.; national library, extraordinary expenses for printing the catalogue, $2000 l$. ; ordinary expenses, 2I,000l. ; other public libraries, I2,000l.; aid to men of science and letters, $8000 l$.; scientific travelling and exploring, 8000l.; College de France, 19,000l.; Museum of Natural History, 36,000l.; Institute of France, 28,000l., of which $8000 \%$. are granted to the Academy of Sciences; Academy of Medicine, $3000 l$; School of Hautes-Etudes, 12,000l.; astronomical and meteorological establishments, 35,000l. ; including a school for astronomers, which has been opened at the Observatoire of Paris, but will be closed as soon as the several French observatories will have procured a sufficient number of trained observers. The commission refuse to grant money to the meteorological observatory of Mount Ventoux.

\section{SCIENTIFIC SERIALS}

Fournal of the Franklin Institute, June.-On the several efficiencies of the steam-engine, and on the conditions of maximum economy (continued), by R. H. Thurston.-Ninety miles in sixty minutes (continued), by W. B. Le Van.-Ringing bells, by J. W. Nystrom.-Radio-dynamics; universal phyllotaxy, by P. E. Chase.-A thermograph, a new apparatus for making a continuous graphical record of the variations of temperature, by G. M. Eldridge.-Electricity, by A. E. Outerbridge, jun.-An essay on mechanics and the progress of mechanical science, $1824-82$, by F. Finley.-Device for increasing the dynamic effect of the pulsations of diaphragms and the like, by W. B. Cooper.-Influence of pulley-diameter on the driving power of flat belts, by $\mathrm{R}$. Grimshaw.-Recent improvements in the mechanic arts, by F. B. Brock.

Bulletin de l'Academie Royale des Sciences de Belgique, No. 4. - History of the Imperial and Royal Academy of Sciences and Belles-Lettres of Brussels, by M. Mailly.-On the dilatation of alums, by M. Spring.-One word more on the determination of latitude, by M. Folie.-On the rocks of the island of Fernando Noronha, gathered during the Challenger expedition, by $M$. Renard.--On the state of vegetation, March 2I, I882, by $M$. Dewalque.-On the respiratory variations of the sanguineous pressure in the rabbit, by MM. Moreau and Lecrenier.-Mineralogical examination of the rocks which accompany the diamond in the mines of the Cape of Good Hope, by M. Meunier.

Reale Istituto Lombardo di Scienze e Lettere. Rendiconti, vol. xv., fasc. ix.-x. - On the nature and origin of tumours occasionally found free in the abdominal cavity, by S. Sangalli. - Presentation of a piece of wood from Brazil, with the apparent figure of a serpent, by Dr. Mantegazza.-On protistological examination of the water of Lake Maggiore, extracted at 60 metres depth, between Angera and Arona, by S. Maggi.-Zoological notes, by S. Pavesi.

Rivista Scientifico-Industriale, April 30 and May 15.-New seismic apparatus of the Brothers Brassart, by S. E. Brassart.The comets seen in the last ten years and Comet Wells, by S. Zona. - On sounds produced by outfiow of liquids, by S. Martini. -On succinine, by Drs. Funaro and Danesi.-Sinaxylon muri. catum, Fab., in the Romagna, by S. Rovelli. - The story of a flint stone, by S. Mascarine.

\section{SOCIETIES AND ACADEMIES LONDON}

Zoological Society, June 20.-Dr. A. Günther, F.R.S., vice-president, in the chair. - The Secretary exhibited a series of the diurnal and nocturnal Lepidopterous insects bred in the Insect House in the Gardens during the present season, and called attention to several specimens of clear-winged Moths (Sesiide), a group of insects which had not before been exhibited in the Insect House. The cocoon of Cricula trifenestrati, together with the imago, was also exhibited.-Mr. W. A. Forbes made remarks on the presence of a rudimentary hallux in certain birds - the Albatrosses and two genera of Woodpeckers (Tiga and Picoides), commonly described as being three-toed, and exhibited preparations showing its condition in the birds in question.-Prof. Owen read the twenty-fifth of his series of memoirs on the Dinornis. The present communication gave a description of the head and feet, with their dried integuments, of an individual of a species supposed to be called Dinornis didina. These specimens had been obtained by $\mathrm{Mr}$. H. L. Squires at Queenstown, South Island of New Zealand, and being parts of one individual tended to elucidate in an unlooked for degree the external characters of the Moa.-A second communication from Prof. Owen contained some observations on Trichina spiralis.-Prof. E. Ray Lankester gave a description of the valves of the heart of Ornithorhynchus paradoxus, and compared them with those of man and the rabbit. Prof. Lankester also made some observations on the fossa ovalis of the Monotremes. - Prof. Huxley, F.R.S., read a description of the respiratory organs of Apteryx, which he showed did not differ fundamentally from the Avian type, and pointed out that neither of the structures that had been termed diaphragms in the Apteryx was really in correspondence with the Mammalian diaphragm. - Mr. W. A. Forbes read the sixth of his contributions to the anatomy of Passerine birds. In the present communication the author showed that Xenicus and Acanthisitta, hitherto considered to be allied to Certhia, Sitta, and Sittella, were really mesomyodian forms, most nearly allied perhaps to Pitta. The discovery of such low forms of Passerine birds in New Zealand was a fact of considerable interest, none of the allied groups being at all represented there at the present day.-A communication was read from $\mathrm{Mr}$. Sylvanus Hanley on the shells of the genus Leplomya, to which was added the descriptions of two new species.-Mr. Sclater read a note on Ruippell's Parrot, and showed that the more brightly-coloured individuals, ordinarily supposed to be the males of this parrot, were really the females. - A second paper from Mr. Sclater gave the description of two new species of the genus Synallaxis from the collection of Messrs. Salvin and Godman.-A communication was read from Prof. M. Watson containing an account of the muscular anatomy of Proteles as compared with that of Hycena and Viverra.-Mr. Oldfield Thomas read a paper containing a description of a new species of Rat from China. The specimens upon which the author had founded the description had been sent by the Abbé Armand David to Mr. Milne-Edwards, of Paris, who had placed them in the hands of Mr. Thomas for identification. The author proposed to call this Rat Mus Edzeardsi.-A communication was read from Mr. E. W. White, F.Z.S., of Buenos Ayres, in which he gave an account of the birds collected by him in the Argentine Republic.-Mr. K. Bowdler Sharpe read the descriptions of two apparently new 